\title{
Heat Stress Increases In Vitro Hindgut Fermentation of Distinct Substrates in Iberian Pigs
}

\author{
Zaira Pardo ${ }^{1}$, Iván Mateos 2,3 ${ }^{(1)}$, Rómulo Campos 2,4 ${ }^{\text {, Andrea Francisco }}{ }^{2}$, Manuel Lachica ${ }^{1}$, \\ María José Ranilla ${ }^{2,3}$ and Ignacio Fernández-Fígares ${ }^{1, *}$ (D) \\ 1 Departamento de Fisiología y Bioquímica de la Nutrición Animal, Estación Experimental del Zaidín, \\ CSIC, Profesor Albareda 1, 18008 Granada, Spain; zaira.pardo@eez.csic.es (Z.P.); \\ manuel.lachica@eez.csic.es (M.L.) \\ 2 Departamento de Producción Animal, Universidad de León, Campus de Vegazana s/n, 24071 León, Spain; \\ imata@unileon.es (I.M.); rcamposg@unal.edu.co (R.C.); afranr03@estudiantes.unileon.es (A.F.); \\ mjrang@unileon.es (M.J.R.) \\ 3 Instituto de Ganadería de Montaña, CSIC-Universidad de León, Finca Marzanas s/n, \\ Grulleros, 24346 León, Spain \\ 4 Departamento de Ciencia Animal, Universidad Nacional de Colombia, Carrera 32 \# 12-00, \\ Palmira 76531, Colombia \\ * Correspondence: ifigares@eez.csic.es
}

Received: 30 October 2020; Accepted: 19 November 2020; Published: 21 November 2020

Simple Summary: Heat stress is a major concern in pig production in summer, as pigs have a limited number of functional sweat glands to transfer body heat. Above $25^{\circ} \mathrm{C}$ pigs are out of their comfort zone and mechanisms such as decreasing feed intake or diverting blood from the internal organs to the skin are triggered. Intestinal microbiota is also affected by high ambient temperature but the consequences on fermentation capacity are poorly known. Short-chain fatty acids are the end-products of bacterial metabolism of carbohydrates and protein mainly in the hindgut and, in addition to being a source of energy, they have beneficial effects on immune status and health. An understanding of the effects of heat stress on intestinal fermentation could help to develop strategies mitigating intestinal disorders. We used an in vitro method to assess gas and short-chain fatty acid production, utilizing as inoculum feces from Iberian pigs fed a commercial diet for 28 days under neutral $\left(20^{\circ} \mathrm{C}\right)$ or heat stress $\left(30^{\circ} \mathrm{C}\right)$ conditions. Four substrates with dissimilar fermentation characteristics were incubated in vitro with fecal inoculum for $24 \mathrm{~h}$. Chronic heat stress increased in vitro production of short-chain fatty acids, suggesting a modification of intestinal microbiota activity.

Abstract: Heat stress reduces the feed intake and growth of pigs. We hypothesized that heat stress affects the intestinal fermentation capacity of pigs. Sixteen Iberian pigs $(44 \pm 1.0 \mathrm{~kg})$ were randomly assigned to one of two treatments (eight pigs/treatment) for 4 weeks-heat stress (HS; $30^{\circ} \mathrm{C}$ ) ad libitum or thermoneutral $\left(\mathrm{TN} ; 20^{\circ} \mathrm{C}\right)$ pair feeding. Frozen rectum contents were used as inocula for $24 \mathrm{~h}$ in vitro incubations in which a mixture of starches, citrus pectin, inulin from chicory, and cellulose were the substrates. Cellulose was poorly degraded, whereas pectin and the mixture of starches were the most fermentable substrates according to total short-chain fatty acid (SCFA) production. The mixture of starches and inulin produced the greatest amount of gas. For all substrates, heat stress enhanced gas production $(8 \%, p=0.001)$, total SCFA production $(16 \%, p=0.001)$, and the production of acetate and propionate $(12 \%$ and $42 \%$, respectively; $p=0.001)$. The increased isoacid production $(33 \%, p=0.001)$ and ammonia concentration $(12 \%, p=0.001)$ may indicate protein fermentation under heat stress. In conclusion, the in vitro intestinal fermentation capacity of pigs under heat stress was increased compared to thermoneutral conditions, which may indicate an adaptive response to heat stress. 
Keywords: heat stress; Iberian pig; in vitro hindgut fermentation; short-chain fatty acids

\section{Introduction}

The increasing environmental temperature due to global warming affects animal health and production worldwide [1,2]. The main pig producing areas in Spain may be classified as having Mediterranean and hot semi-arid climates (https://en.climate-data.org/europe/spain-5/), where high ambient temperatures are common during summer (July-August), with average highs of $32{ }^{\circ} \mathrm{C}-36{ }^{\circ} \mathrm{C}$ in July. Heat stress reduces feed intake and causes intestinal injury, affecting the growth performance of pigs [3]. Some of these effects are generated by hypoxia caused by redirected blood flow from viscera to the skin [4]. The heat dissipation capacity of pigs is impaired because of their scattered sweat glands, which makes them specifically sensitive to heat stress [5]. The Iberian pig (Sus mediterraneus) is the most important Mediterranean native breed, producing cured products of outstandingly high quality. Pure Iberian pigs have traditionally been reared free range, enduring the climatological conditions of each season. Although Iberian pigs are rustic animals, their elevated subcutaneous fat could make them particularly sensitive to the high temperatures of the summer. Heat stress modifies the intestinal microbiota of growing pigs [6], growing-finishing pigs [7] and primiparous sows [8], leading to increased morbidity, as well as altered nutrient digestion and energy metabolism [9]. Microbiota in the large intestine use undigested carbohydrates and protein to substantially generate short-chain fatty acids (SCFA), which are meaningful for the animal as energy and signaling molecules [10]. As in vivo studies are difficult and cumbersome to carry out, in vitro methods are an alternative way to study intestinal fermentation, allowing testing fermentable substrates without the interference of other feed components [11]. The use of in vitro methods to characterize the fermentation of feed ingredients by intestinal microbes and its influence on digestive physiology in pigs is recent [12-15] compared to the use of these methods in ruminants (e.g., $[16,17]$ ). We have used a method based on the in vitro fermentation of a substrate by microbiota from feces of donor pigs, mimicking the fermentation taking place in the large intestine. It is a non-invasive technique for the comparative assessment of fermentation characteristics of feed ingredients and allows for the study of the fermentation capacity of the pig donor. Although the effects of heat stress on SCFA concentrations in different sections of gastrointestinal tracts of pigs have been studied $[7,8,18]$, to our knowledge, there is no information regarding how in vitro fermentation characteristics are affected by heat stress. Furthermore, to the best of our knowledge, the fermentation of pure substrates by Iberian pig inoculum has not been investigated.

We hypothesized that long term heat stress (four weeks, $30^{\circ} \mathrm{C}$ ) would derange the fermentation capacity of pigs. We chose substrates with distinct fermentation characteristics, as their properties may influence fermentation end-products. The aim of this study was to determine differences in the hindgut fermentation of chemically disparate substrates by Iberian pigs in vitro, as affected by heat stress.

\section{Materials and Methods}

\subsection{Animals, Treatments, and Diets}

Experimental procedures and animal care were in agreement with Spanish Ministry of Agriculture guidelines (RD53/2013). Procedures used were approved by the Bioethical Committee of the Spanish Council for Scientific Research (CSIC, Spain) and the competent local authority (Junta de Andalucía, Spain, project authorization 28/06/2016/118).

Sixteen pure Iberian barrows $(44.0 \pm 1.00 \mathrm{~kg})$ from Sanchez Romero Carvajal (Puerto de Santa María, Cádiz, Spain) were used. The experimental diet (Table 1) was based on barley-corn-soybean meal, covering all nutrient requirements. The temperature to induce heat stress was chosen according to the average temperature in the hottest months in the main pig producing areas in Spain and was fixed at $30{ }^{\circ} \mathrm{C}$. Average highs above $32{ }^{\circ} \mathrm{C}-35{ }^{\circ} \mathrm{C}$ are not rare in some producing areas in Spain 
during summer. Accordingly, two experimental treatments were designed $(\mathrm{n}=8)$ —chronic heat stress (HS; $30^{\circ} \mathrm{C} \pm 1{ }^{\circ} \mathrm{C}$, for 4 weeks) fed ad libitum, and thermoneutrality (TN; $22^{\circ} \mathrm{C} \pm 1{ }^{\circ} \mathrm{C}$, for 4 weeks) with pigs pair fed to equal feed intake with HS. For both experimental groups, the temperature was kept constant during the day and night. Feed allowance of pair fed pigs was calculated every day from the estimated daily intake of HS pigs the previous day. The experiment was carried out in 4 replicates, each with two pigs per treatment. Feed intake was calculated on a dry matter basis by collecting feed refusals daily. At arrival, the pigs were randomly assigned to individual partially slatted pens $(2 \times 1 \mathrm{~m})$ for one week in thermoneutral conditions for acclimatization to facilities. Two separated climate-controlled rooms (TN and HS treatments) were used, in which temperature was controlled using an air conditioning apparatus (LG UM36, LG Electronics Inc., Changwon, South Korea). The temperature and relative humidity inside each room were recorded during the study with the aid of a data logger (HOBO UX100-011; Onset Computer Corporation, Bourne, MA, USA) set to register those values every $15 \mathrm{~min}$. The temperature transition from $22^{\circ} \mathrm{C}$ to $30^{\circ} \mathrm{C}$ occurred gradually over $8 \mathrm{~h}$ at a constant rate of $+1^{\circ} \mathrm{C}$ per hour.

Table 1. Composition and chemical analysis $(\mathrm{g} / \mathrm{kg})$ of the experimental diet.

\begin{tabular}{lc}
\hline Ingredients & \\
\hline Barley grain & 700 \\
Corn & 143.7 \\
Soybean meal & 127 \\
Calcium phosphate & 9.3 \\
Calcium carbonate & 6.2 \\
Sodium chloride & 3.0 \\
Vitamins and minerals & 3.0 \\
L-Lysine (50\%) & 5.0 \\
L-Threonine (50\%) & 2.1 \\
Methionine hydroxy-analog (75\%) & 0.7 \\
\hline Chemical Analysis & \\
\hline Dry matter & 899 \\
Ash & 49.0 \\
Crude protein & 141.1 \\
Crude fiber & 41.0 \\
Ether extract & 19.0 \\
Calcium & 6.8 \\
Phosphorous & 6.3 \\
Sodium & 1.6 \\
Lysine & 9.0 \\
Methionine & 2.4 \\
Gross energy (MJ/kg) & 16.6 \\
\hline
\end{tabular}

After the adaptation period, the animals were under TN or HS treatment for four weeks. The pigs in the present experiment were also utilized in a growth trial and were slaughtered at the end of the experimental period $(62 \pm 1.3 \mathrm{~kg})$ by electrical stunning and instant vertical exsanguination and a sample of rectum content was collected $\left(\mathrm{CO}_{2}\right.$-filled container), rapidly frozen and kept at $-20{ }^{\circ} \mathrm{C}$ until the fermentation experiment.

\subsection{Substrates and In Vitro Incubations}

Substrates differing in sugar composition and linkages between sugars were selected, as these factors affect fermentation. Starch (glucose polymer with 1,4-alpha linkage) and cellulose (glucose polymer 1,4-beta bond) are homoglucans; inulin is a fructan (fructose or sucrose units linked by $\beta$-2,1-linkages); and pectin is a polyuronide (partly branched polymer from d-galacturonic acid with 1,4 linkage). A mix of starches (2 corn starch (SIGMA S-4126), 2 potato starch (SIGMA S-2004), 
and 1 wheat starch (SIGMA S-2760)); pectin from citrus pulp (SIGMA P-9135); inulin from chicory (SIGMA I-2255-25G); and microcrystalline cellulose (Merck 1-02331.0500) were used as substrates for the in vitro incubations. These substrates were dried overnight at $40{ }^{\circ} \mathrm{C}$ and $200 \mathrm{mg}$ of dry substrate were weighted into $120 \mathrm{~mL}$ glass bottles.

The day of the incubation, feces were defrosted at room temperature and pooled (an identical amount of feces from two pigs from each experimental condition and an in vivo replicate were used to compose one inoculum). The experiment was repeated in four runs corresponding to the in vivo replicates. In each run, duplicated bottles of each of the five substrates were incubated with both inocula (TN and HS). Blanks (two per inoculum and run) were used to correct the gas production values for gas release from endogenous substrates. Values from the two bottles per substrate and experimental treatments were averaged before statistical analysis, and therefore there were four values per substrate and experimental treatment.

Inoculum preparation was as follows: $25 \mathrm{~g}$ of thawed feces and $500 \mathrm{~mL}$ of the buffered anaerobic culture medium salts of Goering and Van Soest [19] without trypticase added, were mixed $\left(5 \% \mathrm{wt} / \mathrm{vol}\right.$ final concentration of feces) and homogenized in Stomacher ${ }^{\circledR}$ (model number BA6021, Seward Medical, London, UK) at $230 \mathrm{rpm}$ for one minute. The homogenate was filtered through a nylon bag ( $200 \mu \mathrm{m}$ mesh screen). The mixture of diluted feces obtained was added $(30 \mathrm{~mL})$ into each bottle under $\mathrm{CO}_{2}$ flushing. Bottles were sealed with rubber stoppers and aluminium caps and incubated $\left(39^{\circ} \mathrm{C}\right)$ for $24 \mathrm{~h}$.

\subsection{Analysis of Samples}

After $24 \mathrm{~h}$ of incubation, gas production was measured using a pressure transducer (Delta Ohm DTP704-2BGI, Herter Instruments SL, Barcelona, Spain) and a calibrated syringe. A gas sample (10 mL) was stored in an evacuated tube (Terumo Europe N.V., Leuven, Belgium) for the analysis of methane. Bottles were then uncapped and the fermentation was stopped by quenching the bottles in ice water. A liquid sample was immediately obtained $(4 \mathrm{~mL}$ ) from each bottle, mixed with $100 \mu \mathrm{L}$ of $20 \%$ sulfuric acid to preserve the sample and stored at $-20^{\circ} \mathrm{C}$ until analysis for SCFA and ammonia.

\subsubsection{Short-Chain Fatty Acid Analysis}

Liquid samples from the bottles were manipulated as described by Saro et al. [20]. Concentrations of SCFA were determined using a GC-2010 gas chromatograph (Shimadzu, Duisburg, Germany). The amounts of SCFA produced were obtained by subtracting the amount present initially in the inoculum from that determined at the end of the incubation period.

\subsubsection{Ammonia and Methane Analysis}

Liquid samples were defrosted and centrifuged and the supernatant was analyzed for ammonia using colorimetry, following the technique of Weatherburn [21].

Gas samples were analyzed for methane in a gas chromatograph (Shimadzu GC 14B, Shimadzu Europa GmbH, Duisburg, Germany) following the procedures described by Martinez et al. [22].

\subsection{Statistical Analysis}

Data were analyzed using the PROC MIXED of SAS as mixed model, including treatment, substrate and treatment $\times$ substrate as fixed effects and incubation run as a random effect. When a significant treatment $\times$ substrate $(p<0.05)$ was detected, differences among means were tested using Tukey's multiple comparison test. Results were considered significant at $p<0.05$ and trends at $0.05<p<0.10$.

\section{Results}

As anticipated, the feed intake of heat stressed and thermoneutral pair fed pigs used to obtain fecal inocula in the present experiment was similar (2285 g dry matter/day). Additionally, no differences 
were found in average daily gain ( $545 \mathrm{~g} /$ day), gain:feed $(0.24)$ and final weight $(60.3 \mathrm{~kg})$ between TN and HS pigs (unpublished results).

\subsection{Differences in Substrate In Vitro Fermentation}

Gas production and fermentation parameters of the four substrates are shown in Tables $2-4$. There was a significant substrate $\times$ inoculum interaction for most parameters determined $(p<0.05)$, as expected because of the contrasting fermentability characteristics of the substrates.

Table 2. Individual and total short-chain fatty acid (SCFA, $\mu \mathrm{mol}$ ) production after $24 \mathrm{~h}$ in vitro fermentation of four substrates (Subs) by fecal inocula obtained from pigs under thermoneutral (TN) or heat stress (HS) conditions.

\begin{tabular}{|c|c|c|c|c|c|c|c|}
\hline \multirow[b]{2}{*}{ SCFA Production } & \multirow[b]{2}{*}{ Subs } & \multicolumn{2}{|c|}{ Treatment } & \multirow[b]{2}{*}{ SEM $^{1}$} & \multicolumn{3}{|c|}{$p$-Value } \\
\hline & & TN & HS & & Subs & Trt & Subs $\times$ Trt \\
\hline \multirow[t]{4}{*}{ Total SCFA } & Mix of starches & $1546^{\mathrm{A}}$ & $1809^{A *}$ & 15.4 & 0.001 & 0.001 & 0.001 \\
\hline & Pectin & $1789^{\mathrm{B}}$ & $2011^{\mathrm{B} *}$ & & & & \\
\hline & Inulin & $1211^{\mathrm{C}}$ & $1410^{C *}$ & & & & \\
\hline & Cellulose & $118^{\mathrm{D}}$ & $166^{\mathrm{D}}$ & & & & \\
\hline \multirow[t]{4}{*}{ Acetate } & Mix of starches & $788^{A}$ & $947^{A *}$ & 12.2 & 0.001 & 0.001 & 0.001 \\
\hline & Pectin & $1442^{\mathrm{B}}$ & $1603^{\mathrm{B} *}$ & & & & \\
\hline & Inulin & $741^{\mathrm{A}}$ & $765^{C}$ & & & & \\
\hline & Cellulose & $62.0^{\mathrm{C}}$ & $84.0^{\mathrm{D}}$ & & & & \\
\hline \multirow[t]{4}{*}{ Propionate } & Mix of starches & $438^{\mathrm{A}}$ & $509^{A *}$ & 7.9 & 0.001 & 0.001 & 0.001 \\
\hline & Pectin & $151^{\mathrm{B}}$ & $221^{\mathrm{B} *}$ & & & & \\
\hline & Inulin & $285^{C}$ & $512^{A *}$ & & & & \\
\hline & Cellulose & $23.0^{\mathrm{D}}$ & $35.0^{\mathrm{C}}$ & & & & \\
\hline \multirow[t]{4}{*}{ Butyrate } & Mix of starches & $303^{A}$ & $343^{A *}$ & 4.4 & 0.001 & 0.366 & 0.001 \\
\hline & Pectin & $185^{\mathrm{B}}$ & $174^{\mathrm{B}}$ & & & & \\
\hline & Inulin & $177^{\mathrm{B}}$ & $119^{C *}$ & & & & \\
\hline & Cellulose & $20.0^{C}$ & $28.0^{\mathrm{D} *}$ & & & & \\
\hline \multirow[t]{4}{*}{ Isoacids $^{2}$} & Mix of starches & $6.1^{\mathrm{A}}$ & $8.6^{\mathrm{AB}}$ & 0.37 & 0.001 & 0.015 & 0.434 \\
\hline & Pectin & $8.1^{\mathrm{B}}$ & $11.4^{\mathrm{BC}}$ & & & & \\
\hline & Inulin & $4.2^{\mathrm{A}}$ & $4.7^{\mathrm{A}}$ & & & & \\
\hline & Cellulose & $11.6^{\mathrm{C}}$ & $15.4^{C *}$ & & & & \\
\hline \multirow[t]{4}{*}{ Valerate } & Mix of starches & $2.2^{\mathrm{A}}$ & $1.9^{\mathrm{A}}$ & 0.14 & 0.039 & 0.001 & 0.001 \\
\hline & Pectin & $3.6^{\mathrm{B}}$ & $1.5^{\mathrm{A} *}$ & & & & \\
\hline & Inulin & $3.3^{\mathrm{B}}$ & $1.2^{\mathrm{B} *}$ & & & & \\
\hline & Cellulose & $1.8^{\mathrm{A}}$ & $3.6^{C *}$ & & & & \\
\hline
\end{tabular}

${ }^{1}$ Standard error of mean. ${ }^{2}$ Isoacids: isobutyrate + isovalerate. ${ }^{A, B, C, D}$ Means within a column with different superscript are significantly different; $p<0.05$. ${ }^{*}$ Within a row, means with * are significantly different; $p<0.05$.

Table 3. Acetate:propionate ratio and molar proportions of short-chain fatty acids after $24 \mathrm{~h}$ in vitro fermentation of four substrates (Subs) by fecal inocula obtained from pigs under thermoneutral (TN) or heat stress (HS) conditions.

\begin{tabular}{clcccccc}
\hline & \multicolumn{1}{c}{ Treatment } & \multicolumn{3}{c}{$p$-Value } \\
\hline Variable & \multicolumn{1}{c}{ Subs } & TN & HS & SEM $^{\mathbf{1}}$ & Subs & Trt & Subs $\times$ Trt \\
\hline Acetate/Propionate & Mix of starches & $3.6^{\mathrm{A}}$ & $2.4^{\mathrm{A} *}$ & 0.25 & 0.001 & 0.001 & 0.001 \\
& Pectin & $15.6^{\mathrm{B}}$ & $9.2^{\mathrm{B} *}$ & & & & \\
& Inulin & $3.1^{\mathrm{A}}$ & $2.1^{\mathrm{A} *}$ & & & & \\
& Cellulose & $3.9^{\mathrm{A}}$ & $3.5^{\mathrm{C}}$ & & & & \\
Molar proportions & & & & & & & \\
\hline
\end{tabular}


Table 3. Cont.

\begin{tabular}{|c|c|c|c|c|c|c|c|}
\hline \multirow[b]{2}{*}{ Variable } & \multirow[b]{2}{*}{ Subs } & \multicolumn{2}{|c|}{ Treatment } & \multirow[b]{2}{*}{ SEM $^{1}$} & \multicolumn{3}{|c|}{$p$-Value } \\
\hline & & TN & HS & & Subs & Trt & Subs $\times \operatorname{Trt}$ \\
\hline \multirow[t]{4}{*}{ Acetate } & Mix of starches & $51.0^{\mathrm{A}}$ & $52.2 \mathrm{AB}$ & 0.51 & 0.001 & 0.097 & 0.029 \\
\hline & Pectin & $81.0^{\mathrm{B}}$ & $80.2^{C}$ & & & & \\
\hline & Inulin & $61.0^{\mathrm{C}}$ & $55.7^{\mathrm{A}}$ & & & & \\
\hline & Cellulose & $54.3^{\mathrm{D}}$ & $50.5^{\mathrm{B}}$ & & & & \\
\hline \multirow[t]{4}{*}{ Propionate } & Mix of starches & $25.2^{\mathrm{A}}$ & $26.4^{\mathrm{A}}$ & 0.35 & 0.001 & 0.001 & 0.001 \\
\hline & Pectin & $8.1^{\mathrm{B}}$ & $10.7^{\mathrm{B} *}$ & & & & \\
\hline & Inulin & $23.3^{\mathrm{A}}$ & $33.8^{C *}$ & & & & \\
\hline & Cellulose & $17.0^{\mathrm{C}}$ & $18.0^{\mathrm{D}}$ & & & & \\
\hline \multirow[t]{4}{*}{ Butyrate } & Mix of starches & $22.4^{\mathrm{A}}$ & $20.8^{\mathrm{A}}$ & 0.38 & 0.001 & 0.012 & 0.030 \\
\hline & Pectin & $10.2^{\mathrm{B}}$ & $8.5^{\mathrm{B} *}$ & & & & \\
\hline & Inulin & $14.9^{C}$ & $9.6^{\mathrm{B} *}$ & & & & \\
\hline & Cellulose & $17.2^{\mathrm{D}}$ & $16.8^{\mathrm{C}}$ & & & & \\
\hline \multirow[t]{4}{*}{ Isoacids $^{2}$} & Mix of starches & $0.41^{\mathrm{A}}$ & $0.48^{\mathrm{A}}$ & 0.15 & 0.001 & 0.021 & 0.004 \\
\hline & Pectin & $0.45^{\mathrm{A}}$ & $0.56^{\mathrm{A}}$ & & & & \\
\hline & Inulin & $0.39^{\mathrm{A}}$ & $0.31^{\mathrm{A}}$ & & & & \\
\hline & Cellulose & $10.1^{\mathrm{B}}$ & $10.4^{\mathrm{B}}$ & & & & \\
\hline \multirow[t]{4}{*}{ Valerate } & Mix of starches & $0.14^{\mathrm{A}}$ & $0.10^{\mathrm{A} *}$ & 0.06 & 0.001 & 0.365 & 0.009 \\
\hline & Pectin & $0.19^{\mathrm{A}}$ & $0.08^{\mathrm{A} *}$ & & & & \\
\hline & Inulin & $0.24^{\mathrm{A}}$ & $0.60^{B *}$ & & & & \\
\hline & Cellulose & $1.16^{\mathrm{B}}$ & $1.02^{C}$ & & & & \\
\hline
\end{tabular}

${ }^{1}$ Standard error of mean. ${ }^{2}$ Isoacids: isobutyrate + isovalerate. ${ }^{\mathrm{A}, \mathrm{B}, \mathrm{C}, \mathrm{D}}$ Means within a column with different superscript are significantly different; $p<0.05$. ${ }^{*}$ Within a row, means with ${ }^{*}$ are significantly different; $p<0.05$.

Table 4. Gas and methane $\left(\mathrm{CH}_{4}\right)$ production $(\mu \mathrm{mol})$ and concentrations of ammonia $(\mathrm{mg} / \mathrm{L})$ after $24 \mathrm{~h}$ in vitro fermentation of four substrates (Subs) by fecal inocula obtained from pigs under thermoneutral (TN) or heat stress (HS) conditions.

\begin{tabular}{|c|c|c|c|c|c|c|c|}
\hline \multirow[b]{2}{*}{ Variable } & \multirow[b]{2}{*}{ Subs } & \multicolumn{2}{|c|}{ Treatment } & \multirow[b]{2}{*}{ SEM $^{1}$} & \multicolumn{3}{|c|}{$p$-Value } \\
\hline & & TN & HS & & Subs & Trt & Subs $\times$ Trt \\
\hline \multirow[t]{4}{*}{ Gas production } & Mix of starches & $3079^{\text {A }}$ & $3338^{A *}$ & 13.5 & 0.001 & 0.001 & 0.002 \\
\hline & Pectin & $3000 \mathrm{AB}$ & $3296^{\mathrm{A} *}$ & & & & \\
\hline & Inulin & $2912^{\text {B }}$ & $3001^{\mathrm{B} *}$ & & & & \\
\hline & Cellulose & $584^{C}$ & $707^{C *}$ & & & & \\
\hline \multirow[t]{4}{*}{$\mathrm{CH}_{4}$ production } & Mix of starches & $402^{A}$ & $412^{\mathrm{A}}$ & 5.5 & 0.001 & 0.319 & 0.045 \\
\hline & Pectin & $426^{\mathrm{A}}$ & $457^{\mathrm{A}}$ & & & & \\
\hline & Inulin & $402^{\mathrm{A}}$ & $404^{\mathrm{A}}$ & & & & \\
\hline & Cellulose & $293^{B}$ & $236^{\mathrm{B} *}$ & & & & \\
\hline \multirow[t]{4}{*}{ Ammonia } & Mix of starches & $121^{\mathrm{A}}$ & $128^{\mathrm{A}}$ & 1.1 & 0.001 & 0.001 & 0.040 \\
\hline & Pectin & $145^{\mathrm{B}}$ & $171^{\mathrm{B} *}$ & & & & \\
\hline & Inulin & $124^{\mathrm{A}}$ & $144^{C *}$ & & & & \\
\hline & Cellulose & $230^{C}$ & $252^{\mathrm{D} *}$ & & & & \\
\hline
\end{tabular}

\footnotetext{
${ }^{1}$ Standard error of mean. ${ }^{\mathrm{A}, \mathrm{B}, \mathrm{C}, \mathrm{D}}$ Means within a column with different superscript are significantly different;
} $p<0.05$. *Within a row, means with * are significantly different; $p<0.05$.

According to total SCFA (sum of acetate, propionate, butyrate, isoacids, and valerate) and gas production measurements (Tables 2 and 4), the most fermentable substrates were pectin and the mix of starches, whereas cellulose was hardly fermented. Indeed, the average total SCFA production of pectin was $1900 \mu \mathrm{mol}$, compared to $142 \mu \mathrm{mol}$ for cellulose (Table 2, $p=0.001$ ), and the average gas production of the mix of starches was $3209 \mu \mathrm{mol}$, compared to $646 \mu \mathrm{mol}$ for cellulose (Table $4, p=0.001$ ). 
Pectin produced the greatest amount of acetate $(1523 \mu \mathrm{mol}$ on average $)$ and cellulose produced the lowest (73 $\mu \mathrm{mol}$ on average) (Table 2). Propionate production was the greatest $(p=0.001)$ for the mix of starches ( $474 \mu \mathrm{mol}$ on average), followed by inulin ( $399 \mu \mathrm{mol}$ on average), and the lowest was observed for cellulose ( $29 \mu \mathrm{mol}$ on average). Butyrate production was the greatest $(p=0.001)$ for the mix of starches ( $323 \mu \mathrm{mol}$ on average), followed by pectin and inulin (180 and $148 \mu \mathrm{mol}$ on average, respectively). Isoacid production was the greatest $(p=0.001)$ for cellulose $(14 \mu \mathrm{mol}$ on average), followed by pectin $(10 \mu \mathrm{mol}$ on average), compared to the rest of substrates ( $6 \mu \mathrm{mol}$ on average).

The acetate:propionate ratio (Table 3) was the greatest for pectin compared to the other substrates (12 vs. 3, respectively, $p=0.001)$. The acetate molar proportion was $(p=0.001)$ the highest for pectin ( $81 \%$ on average) and the lowest for cellulose and the mix of starches ( $52 \%$ on average), whereas inulin was intermediate ( $58 \%$ on average). Pectin showed the lowest $(p=0.001)$ propionate molar proportion ( $9 \%$ on average), the mix of starches and inulin showed the highest ( $27 \%$ on average), and cellulose showed an intermediate proportion (18\% on average). Pectin showed the lowest butyrate molar proportion ( $9 \%$ on average, $p=0.001)$, whereas the mix of starches was the highest ( $22 \%$ on average). Cellulose had the highest isoacid molar proportion (10\% on average, $p=0.001)$ compared to the other substrates $(0.4 \%$ on average).

Methane production (Table 4$)$ was the lowest $(p=0.001)$ for cellulose (293 $\mu \mathrm{mol}$ on average), with no differences $(p>0.10)$ for the rest of substrates $(417 \mu$ mol on average).

The ammonia concentration (Table 4$)$ was the largest $(p=0.001)$ for cellulose $(241 \mathrm{mg} / \mathrm{L}$ on average) and the lowest for the mix of starches $(125 \mathrm{mg} / \mathrm{L}$ on average), with pectin and inulin showing intermediate values $(146 \mathrm{mg} / \mathrm{L}$ on average).

\subsection{Effect of Heat Stress on In Vitro Fermentation}

Heat stress increased the capacity of in vitro intestinal fermentation in Iberian pigs, as indicated by augmented total SCFA for all substrates but cellulose ( $16 \%$ across substrates, $p=0.001)$ and gas production ( $8 \%$ across substrates, $p=0.001)$, as shown in Tables 2 and 4 .

Acetate, propionate, and isoacid production were also increased $(12 \%, 42 \%$, and $34 \%$, respectively, across substrates, $p=0.001$ ) as a consequence of heat stress (Table 2).

Heat stress increased the propionate molar proportion for pectin and inulin ( $21 \%$ on average, $p=0.001)$ and decreased the acetate:propionate ratio $(37 \%, p=0.001)$ and the acetate molar proportion only when inulin was the substrate $(9 \%, p=0.001)$ (Table 3$)$. On the other hand, heat stress increased the ammonia concentration (Table 4$)$ for all substrates ( $12 \%$ across substrates, $p=0.001)$ except for the mix of starches.

No differences $(p>0.10)$ in methane production (Table 4) were caused by heat stress for any incubated substrate.

\section{Discussion}

In vitro gas production techniques used to assess gastrointestinal tract fermentation have limitations but also have many advantages [23]. Although in vitro models usually do not take into account the ongoing production and rapid absorption of SCFAs [24] which occurs in vivo, in vitro fermentation provides a reliable technique to estimate SCFA production, as they are not absorbed $[25,26]$. In vitro gas production, SCFA production, and ammonia concentration were used as indicators of fermentation in the large intestine [27]. Feces are highly representative of the microbial activity of digesta from the whole large intestine [28] and can be used as a source of inoculum instead of intestinal contents for in vitro fermentation techniques [29,30]. The frozen cecal content and feces of pigs [31,32], horses [33], and rabbits [34] have successfully been used as inoculum to study hindgut fermentation. Finally, we used $24 \mathrm{~h}$ incubation time, which is both convenient in the laboratory and close to the estimated transit time of digesta in the large intestine of pigs fed cereal-based diets $[35,36]$.

No information in the literature exists regarding the in vitro fermentation of pure substrates by Iberian pigs. We chose to use a variety of substrates to allow for discrimination in the fermentation 
capability of inocula, as the extent of fermentation and the profile in SCFAs depend on the substrate $[37,38]$. The fermentation of dietary fibers is influenced by their chemical characteristics $[39,40]$. For example, it is known that soluble dietary fibers such as inulin and pectin are generally highly fermentable compared to insoluble fibers [41-43], increasing intestinal microbial activity and decreasing transit time [44].

In agreement with previous works using similar substrates $[45,46]$, pectin generated the largest acetate production. The mix of starches showed particularly elevated butyrate production in comparison with the other substrates, in accordance with the literature [46,47]. Butyrate, the fuel for enterocytes [48, 49], has beneficial implications for large intestine health [50], as well as for the immune system [51], and may have a trophic effect on the intestinal epithelium [45,52]. The low gas production and total SCFA production reported for cellulose implicate the limited presence of cellulolytic microbiota, which is supported by the elevated ammonia concentration, similar to the blank (data not shown), indicating that ammonia was not used by microbiota. On the other hand, the reduced concentration of ammonia and production of isoacids by inulin and the mix of starches indicates reduced protein fermentation, which is in agreement with the reduced protein fermentative end-products and bacterial populations associated when fructans were the substrate of fermentation in vivo in pigs, humans, and dogs [53-55]. The fermentation of protein generates ammonia and amines, which are considered toxic for the animal [56,57].

Even when direct comparison between results from different in vitro fermentation studies is not possible, the extent of degradation of the substrates used in the present experiment is in line with those found by other authors when using pectins and starch of different origins [12], hydrolyzed sugar beet pulp [58], or soy pectin and oligofructose [59]. The elevated proportion of acetate after in vitro fermentation of all substrates assayed is in accordance with the literature [60-62]. Likewise, cellulose was poorly used by bacteria, concurring with most fermentation or digestibility studies [63-65]. Other studies, however, have shown that a longer incubation time (72 h) is necessary for cellulose to reach a total gas production comparable to soluble fibers $[66,67]$.

The thermoneutral zone of pigs is between $18{ }^{\circ} \mathrm{C}$ and $25{ }^{\circ} \mathrm{C}$ and temperatures above $25^{\circ} \mathrm{C}$ activate thermoregulatory responses [68]. We chose $22^{\circ} \mathrm{C}$ as thermoneutral and $30^{\circ} \mathrm{C}$ as heat stress temperatures to study the effect of chronic heat stress on the fermentation capacity of pigs in vitro. Additionally, to study the direct effects of heat stress independent of feed intake (heat stress decreases feed intake), pigs in thermoneutral conditions were feed-restricted to assure the same level of intake.

We have found no information on the possible effects of heat stress on the fermentation capacity of pigs in vitro- only limited information about volatile fatty acid concentration in feces or in the hindgut is available $[7,8,18]$.

The acetate:propionate ratio is used in ruminants to characterize the kind of predominant fermentation in the rumen. The lower the ratio, the more efficient. Since propionate is glucogenic, a lower acetate:propionate ratio, as in Iberian HS pigs in the present experiment, indicates increased production and availability of energy. Unexpectedly, heat stress increased total SCFA content for all substrates utilized in our study. Experiments with modern breeds have shown decreased concentrations of SCFA in the feces of growing Duroc $\times$ Large White $\times$ Landrace pigs $(30 \mathrm{~kg}$ ) subjected to acute heat stress ( $35{ }^{\circ} \mathrm{C}$ for $24 \mathrm{~h}$ ) [7] and in the feces of late gestational Landrace $\times$ Large White primiparous sows exposed to chronic heat stress $\left(28^{\circ} \mathrm{C}-32{ }^{\circ} \mathrm{C}\right.$ for 22 days) [8]. Interestingly, the SCFA content in the cecum of finishing pigs fed ad libitum and subjected to daily cyclical heat stress $\left(37^{\circ} \mathrm{C}\right.$ for $9 \mathrm{~h}$ and $27^{\circ} \mathrm{C}$ for $15 \mathrm{~h}$ ) for 28 days was not altered [18]. Temperature and duration of experiments, as well as feed intake, seem to be among the key factors affecting intestinal microbiota and may certainly be responsible for discrepancies between studies. The breed may also play an important role regarding microbiota composition. For instance, gut microbiota is a major contributor to adiposity in pigs [69]. Augmented SCFA may be considered advantageous for the pig as SCFAs promote resistance to opportunistic pathogens including enterotoxigenic Escherichia coli, Clostridum, and Salmonella [54,70]. Additionally, microbial degradation of fiber to SCFA might contribute to the energy maintenance 
requirements of the pig to a considerable extent (15\%-30\%) [71,72]. Finally, butyrate plays a main role as the preferential fuel of enterocytes [48,49] and has been linked to improved gut health [73].

It has recently been reported that fecal microbiota composition is significantly influenced by climatic conditions in growing pigs [6], so it is possible that in the present study, the microbiota of the pigs adapted to heat stress conditions after 4 weeks. Iberian pigs are rustic animals [74] that may be resilient to different stresses. Our results suggest such a resiliency, as the pigs showed increased microbial activity in the large intestine under chronic heat stress. Further research is required to provide evidence on the effect of heat stress on microbiota composition and function in the hindgut of Iberian pigs.

\section{Conclusions}

Heat stress increased the in vitro hindgut fermentation capacity in Iberian pigs. If confirmed in vivo, the augmented SCFA production could be considered a resilience mechanism that limits the negative effects of heat stress.

Author Contributions: Conceptualization, I.F.-F., M.L., and M.J.R.; methodology, M.J.R., R.C., and I.M. validation, M.J.R., R.C., and I.M.; formal analysis, R.C., Z.P., A.F., and I.M. investigation, I.F.-F., M.L., and M.J.R.; resources, I.F.-F.; data curation, A.F., Z.P., and I.M.; writing-original draft preparation, Z.P. and I.F.-F. writing-review and editing, Z.P., I.M., R.C., M.J.R., and I.F.-F.; visualization, I.F.-F.; supervision, M.J.R. and I.F.-F.; project administration, I.F.-F.; funding acquisition, M.L. and I.F.-F. All authors have read and agreed to the published version of the manuscript.

Funding: This research was funded by Ministerio de Economía y Competitividad, grant AGL 2016-80231. Zaira Pardo received a scholarship FPI from Ministerio de Economía y Competitividad, reference BES-2017-081486.

Acknowledgments: This work is part of the PhD Thesis project of Zaira Pardo within the Official Doctorate Program "Nutrition and Food Sciences", University of Granada, Spain. We acknowledge support of the publication fee by the CSIC Open Access Publication Support Initiative through its Unit of Information Resources for Research (URICI).

Conflicts of Interest: The authors declare no conflict of interest. The funders had no role in the design of the study; in the collection, analyses, or interpretation of data; in the writing of the manuscript, or in the decision to publish the results.

\section{References}

1. Renaudeau, D.; Collin, A.; Yahav, S.; de Basilio, V.; Gourdine, J.L.; Collier, R.J. Adaptation to hot climate and strategies to alleviate heat stress in livestock production. Animal 2012, 6, 707-728. [CrossRef]

2. Baumgard, L.H.; Rhoads, R.P. Effects of heat stress on postabsorptive metabolism and energetics. Annu. Rev. Anim. Biosci. 2013, 1, 311-337. [CrossRef]

3. Lambert, G.P. Stress-induced gastrointestinal barrier dysfunction and its inflammatory effects. J. Anim. Sci 2009, 87, E101-E108. [CrossRef]

4. Ingram, D.L.; Legge, K.F. Influence of deep body temperatures and skin temperatures on peripheral blood flow in pig. J. Physiol. Lond. 1971, 215, 693-707. [CrossRef]

5. Renaudeau, D.; Leclercq-Smekens, M.; Herin, M. Differences in skin characteristics in European (Large White) and Caribbean (Creole) growing pigs with reference to thermoregulation. Anim. Res. 2006, 55, 209-217. [CrossRef]

6. Le Sciellour, M.; Zemb, O.; Hochu, I.; Riquet, J.; Gilbert, H.; Giorgi, M.; Billon, Y.; Gourdine, J.L.; Renaudeau, D. Effect of chronic and acute heat challenges on fecal microbiota composition, production, and thermoregulation traits in growing pigs. J. Anim. Sci. 2019, 97, 3845-3858. [CrossRef]

7. Xiong, Y.; Yi, H.; Wu, Q.; Jiang, Z.; Wang, L. Effects of acute heat stress on intestinal microbiota in grow-finishing pigs, and associations with feed intake and serum profile. J. Appl. Microbiol. 2019, 128, 840-852. [CrossRef] [PubMed]

8. He, J.; Guo, H.; Zheng, W.; Xue, Y.; Zhao, R.; Yao, W. Heat stress affects fecal microbial and metabolic alterations of primiparous sows during late gestation. J. Anim. Sci. Biotechnol. 2019, 10, 84. [CrossRef] [PubMed]

9. Nicholson, J.K.; Holmes, E.; Kinross, J.; Burcelin, R.; Gibson, G.; Jia, W.; Pettersson, S. Host-gut microbiota metabolic interactions. Science 2012, 336, 1262-1267. [CrossRef] [PubMed] 
10. Koh, A.; De Vadder, F.; Kovatcheva-Datchary, P.; Backhed, F. From dietary fiber to host physiology: Short-chain fatty acids as key bacterial metabolites. Cell 2016, 165, 1332-1345. [CrossRef]

11. Rymer, C.; Huntington, J.A.; Williams, B.A.; Givens, D.I. In vitro cumulative gas production techniques: History, methodological considerations and challenges. Anim. Feed Sci. Techol. 2005, 123, 9-30. [CrossRef]

12. Williams, B.A.; Bosch, M.W.; Boer, H.; Verstegen, M.W.A.; Tamminga, S. An in vitro batch culture method to assess potential fermentability of feed ingredients for monogastric diets. Anim. Feed Sci. Technol. 2005, 123, 445-462. [CrossRef]

13. Bindelle, J.; Pieper, R.; Montoya, C.A.; Van Kessel, A.G.; Leterme, P. Nonstarch polysaccharide-degrading enzymes alter the microbial community and the fermentation patterns of barley cultivars and wheat products in an in vitro model of the porcine gastrointestinal tract. Fems. Microbiol. Ecol. 2011, 76, 553-563. [CrossRef] [PubMed]

14. Jha, R.; Woyengo, T.A.; Li, J.; Bedford, M.R.; Vasanthan, T.; Zijlstra, R.T. Enzymes enhance degradation of the fiber-starch-protein matrix of distillers dried grains with solubles as revealed by a porcine in vitro fermentation model and microscopy. J. Anim. Sci. 2015, 93, 1039-1051. [CrossRef] [PubMed]

15. Morales, J.; Pérez, J.F.; Martín-Orúe, S.M.; Fondevila, M.; Gasa, J. Large bowel fermentation of maize or sorghum-acorn diets fed as a different source of carbohydrates to Landrace and Iberian pigs. Br. J. Nutr. 2002, 88, 489-498. [CrossRef] [PubMed]

16. Beuvink, J.M.W.; Spoelstra, S.F. Interactions between substrate, fermentation end-products, buffering systems and gas-production upon fermentation of different carbohydrates by mixed rumen microorganisms in vitro. Appl. Microbiol. Biotechnol. 1992, 37, 505-509. [CrossRef]

17. Theodorou, M.K.; Williams, B.A.; Dhanoa, M.S.; McAllan, A.B.; France, J. A simple gas-production method using a pressure transducer to determine the fermentation kinetics of ruminant feeds. Anim. Feed Sci. Technol. 1994, 48, 185-197. [CrossRef]

18. Song, R.; Foster, D.N.; Shurson, G.C. Effects of feeding diets containing bacitracin methylene disalicylate to heat-stressed finishing pigs. J. Anim. Sci. 2011, 89, 1830-1843. [CrossRef]

19. Goering, H.K.; Van Soest, P.J. Forage fiber analyses: Apparatus, reagents, procedures, and some applications. In Agriculture Handbook; Agricultural Research Service, U.S. Dept. of Agriculture: Washintong, DC, USA, 1970; Volume 379.

20. Saro, C.; Mateo, J.; Andres, S.; Mateos, I.; Jose Ranilla, M.; Lopez, S.; Martin, A.; Javier Giraldez, F. Replacing soybean meal with urea in diets for heavy fattening lambs: Effects on growth, metabolic profile and meat quality. Animals 2019, 9, 974. [CrossRef]

21. Weatherburn, M.W. Phenol-hypochlorite reaction for determination of ammonia. Anal. Chem. 1967, 39, 971-974. [CrossRef]

22. Martinez, M.E.; Ranilla, M.J.; Tejido, M.L.; Saro, C.; Carro, M.D. The effect of the diet fed to donor sheep on in vitro methane production and ruminal fermentation of diets of variable composition. Anim. Feed Sci. Technol. 2010, 158, 126-135. [CrossRef]

23. Krishnamoorthy, U.; Rymer, C.; Robinson, P.H. The in vitro gas production technique: Limitations and opportunities. Anim. Feed Sci. Technol. 2005, 123-124, 1-7. [CrossRef]

24. Argenzio, R.A.; Southworth, M. Sites of organic-acid production and absorption in gastrointestinal-tract of pig. Am. J. Physiol. 1975, 228, 454-460. [CrossRef] [PubMed]

25. McBurney, M.I.; Sauer, W.C. Fiber and large bowel energy absorption: Validation of the integrated ileostomy-fermentation model using pigs. J. Nutr. 1993, 123, 721-727. [CrossRef]

26. Regmi, P.R.; Metzler-Zebeli, B.U.; Gaenzle, M.G.; van Kempen, T.A.T.G.; Zijlstra, R.T. Starch with high amylose content and low in vitro digestibility increases intestinal nutrient flow and microbial fermentation and selectively promotes bifidobacteria in pigs. J. Nutr. 2011, 141, 1273-1280. [CrossRef]

27. Williams, B.A.; Bosch, M.W.; Awati, A.; Konstantinov, S.R.; Smidt, H.; Akkermans, A.D.L.; Verstegen, M.W.A.; Tamminga, S. In vitro assessment of gastrointestinal tract (GIT) fermentation in pigs: Fermentable substrates and microbial activity. Anim. Res. 2005, 54, 191-201. [CrossRef]

28. Bauer, E.; Williams, B.A.; Voigt, C.; Mosenthin, R.; Verstegen, M.W.A. Microbial activities of faeces from unweaned and adult pigs, in relation to selected fermentable carbohydrates. Anim. Sci. 2001, 73, 313-322. [CrossRef] 
29. Bauer, E.; Williams, B.A.; Bosch, M.W.; Voigt, C.; Mosenthin, R.; Verstegen, M.W.A. Differences in microbial activity of digesta from three sections of the porcine large intestine according to in vitro fermentation of carbohydrate-rich substrates. J. Sci. Food Agric. 2004, 84, 2097-2104. [CrossRef]

30. Bindelle, J.; Buldgen, A.; Boudry, C.; Leterme, P. Effect of inoculum and pepsin-pancreatin hydrolysis on fibre fermentation mecasured by the gas production technique in pigs. Anim. Feed Sci. Technol. 2007, 132, 111-122. [CrossRef]

31. Suarez-Belloch, J.; Doti, S.; Rodriguez-Romero, N.; Guada, J.A.; Fondevila, M.; Latorre, M.A. Hindgut fermentation in pigs induced by diets with different sources or starch. Span. J. Agric. Res. 2013, 11, 780-789. [CrossRef]

32. Pastorelli, G.; Faustini, M.; Attard, E. In vitro fermentation of feed ingredients by fresh or frozen pig fecal inocula. Anim. Sci. J. 2014, 85, 690-697. [CrossRef] [PubMed]

33. Murray, J.M.D.; McMullin, P.; Handel, I.; Hastie, P.M. The effect of freezing on the fermentative activity of equine faecal inocula for use in an in vitro gas production technique. Anim. Feed Sci. Technol. 2012, 178, 175-182. [CrossRef]

34. Stanco, G.; Di Meo, C.; Piccolo, G.; Nizza, A. Effect of storage duration on frozen inoculum to be used for the in vitro gas production technique in rabbit. Ital. J. Anim. Sci. 2003, 2, 265-270. [CrossRef]

35. Keys, J.E.; Debarthe, J.V. Cellulose and hemicellulose digestibility in stomach, small-intestine and large-intestine of swine. J. Anim. Sci. 1974, 39, 53-56. [CrossRef] [PubMed]

36. Rerat, A.; Fiszlewicz, M.; Giusi, A.; Vaugelade, P. Influence of meal frequency on postprandial variations in the production and absorption of volatile fatty-acids in the digestive-tract of conscious pigs. J. Anim. Sci. 1987, 64, 448-456. [CrossRef] [PubMed]

37. Macfarlane, S.; Macfarlane, G.T. Regulation of short-chain fatty acid production. Proc. Nutr. Soc. 2003, 62, 67-72. [CrossRef]

38. Salvador, V.; Cherbut, C.; Barry, J.L.; Bertrand, D.; Bonnet, C.; Delortlaval, J. Sugar composition of dietary fiber and short-chain fatty-acid production during in-vitro fermentation by human bacteria. Br. J. Nutr. 1993, 70, 189-197. [CrossRef]

39. Jonathan, M.C.; van den Borne, J.J.G.C.; van Wiechen, P.; da Silva, C.S.; Schols, H.A.; Gruppen, H. In vitro fermentation of 12 dietary fibres by faecal inoculum from pigs and humans. Food Chem. 2012, 133, 889-897. [CrossRef]

40. Davidson, M.H.; McDonald, A. Fiber: Forms and functions. Nutr. Res. 1998, 18, 617-624. [CrossRef]

41. McBurney, M.I.; Horvath, P.J.; Jeraci, J.L.; Van Soest, P.J. Effect of in vitro fermentation using human fecal inoculum on the water-holding capacity of dietary fiber. Br. J. Nutr. 1985, 53, 17-24. [CrossRef]

42. Freire, J.P.B.; Guerreiro, A.J.G.; Cunha, L.F.; Aumaitre, A. Effect of dietary fibre source on total tract digestibility, caecum volatile fatty acids and digestive transit time in the weaned piglet. Anim. Feed Sci. Technol. 2000, 87, 71-83. [CrossRef]

43. Knudsen, K.E.B. The nutritional significance of "dietary fibre" analysis. Anim. Feed Sci. Technol. 2001, 90, 3-20. [CrossRef]

44. Wenk, C. The role of dietary fibre in the digestive physiology of the pig. Anim. Feed Sci. Technol. 2001, 90, 21-33. [CrossRef]

45. Salminen, S.; Bouley, C.; Boutron-Ruault, M.C.; Cummings, J.H.; Franck, A.; Gibson, G.R.; Isolauri, E.; Moreau, M.C.; Roberfroid, M.; Rowland, I. Functional food science and gastrointestinal physiology and function. Br. J. Nutr. 1998, 80, S147-S171. [CrossRef] [PubMed]

46. Rink, F.; Bauer, E.; Eklund, M.; Mosenthin, R. Effect of different carbohydrates on in vitro fermentation activity and bacterial numbers of porcine inocula under osmotic stress conditions. Arch. Anim. Nutr. 2011, 65, 445-459. [CrossRef]

47. Cummings, J.H.; Englyst, H.N. Fermentation in the human large-intestine and the available substrates. Am. J. Clin. Nutr. 1987, 45, 1243-1255. [CrossRef] [PubMed]

48. Roediger, W.E.W. Short chain fatty-acids as metabolic regulators of ion absorption in the colon. Acta Vet. Scand. Suppl. 1989, 86, 116-125.

49. Jha, R.; Berrocoso, J.D. Review: Dietary fiber utilization and its effects on physiological functions and gut health of swine. Animal 2015, 9, 1441-1452. [CrossRef]

50. Roediger, W.E.W. Role of anaerobic-bacteria in the metabolic welfare of the colonic mucosa in man. Gut 1980, 21, 793-798. [CrossRef] 
51. Jha, R.; Fouhse, J.M.; Tiwari, U.P.; Li, L.; Willing, B.P. Dietary fiber and intestinal health of monogastric animals. Front. Vet. Sci. 2019, 6, 48. [CrossRef]

52. Metzler, B.; Bauer, E.; Mosenthin, R. Microflora management in the gastrointestinal tract of piglets. Asian-Aust. J. Anim. Sci. 2005, 18, 1353-1362. [CrossRef]

53. Pierce, K.M.; Sweeney, T.; Brophy, P.O.; Callan, J.J.; Fitzpatrick, E.; McCarthy, P.; O’Doherty, J.V. The effect of lactose and inulin on intestinal morphology, selected microbial populations and volatile fatty acid concentrations in the gastro-intestinal tract of the weanling pig. Anim. Sci. 2006, 82,311-318. [CrossRef]

54. Gibson, G.R.; Roberfroid, M.B. Dietary modulation of the human colonic microbiota: Introducing the concept of prebiotics. J. Nutr. 1995, 125, 1401-1412. [CrossRef] [PubMed]

55. Swanson, K.S.; Grieshop, C.M.; Flickinger, E.A.; Bauer, L.L.; Healy, H.P.; Dawson, K.A.; Merchen, N.R.; Fahey, G.C. Supplemental fructooligosaccharides and mannanoligosaccharides influence immune function, ileal and total tract nutrient digestibilities, microbial populations and concentrations of protein catabolites in the large bowel of dogs. J. Nutr. 2002, 132, 980-989. [CrossRef] [PubMed]

56. Cummings, J.H.; Macfarlane, G.T. The control and consequences of bacterial fermentation in the human colon. J. Appl. Bacteriol. 1991, 70, 443-459. [CrossRef] [PubMed]

57. Visek, W.J. Diet and cell-growth modulation by ammonia. Am. J. Clin. Nutr. 1978, 31, 216-220. [CrossRef] [PubMed]

58. Bindelle, J.; Buldgen, A.; Lambotte, D.; Wavreille, J.; Letermen, P. Effect of pig faecal donor and of pig diet composition on in vitro fermentation of sugar beet pulp. Anim. Feed Sci. Technol. 2007, 132, 212-226. [CrossRef]

59. Sappok, M.; Pellikaan, W.F.; Verstegen, M.W.A.; Bosch, G.; Sundrum, A.; Hendriks, W.H. Large intestinal fermentation capacity of fattening pigs on organic farms as measured in vitro using contrasting substrates. J. Sci. Food Agric. 2013, 93, 2402-2409. [CrossRef]

60. McBurney, M.I.; Thompson, L.U. Effect of human fecal inoculum on in vitro fermentation variables. Br. J. Nutr. 1987, 58, 233-243. [CrossRef]

61. Mortensen, P.B.; Rasmussen, H.S.; Holtug, K. Short-chain fatty acid production from mono- and disaccharides in a fecal incubation system: Implications for colonic fermentation of dietary fiber in humans. J. Nutr. 1988, 118, 321-325. [CrossRef]

62. Titgemeyer, E.C.; Bourquin, L.D.; Fahey, G.C.; Garleb, K.A. Fermentability of various fiber sources by human fecal bacteria in vitro. Am. J. Clin. Nutr. 1991, 53, 1418-1424. [CrossRef] [PubMed]

63. McBurney, M.I.; Thompson, L.U. In vitro fermentabilities of purified fiber supplements. J. Food Sci. 1989, 54, 347-350. [CrossRef]

64. Nyman, M.; Schweizer, T.F.; Tyren, S.; Reimann, S.; Asp, N.G. Fermentation of vegetable fiber in the intestinal-tract of rats and effects on fecal bulking and bile-acid excretion. J. Nutr. 1990, 120, 459-466. [CrossRef] [PubMed]

65. Goodlad, J.S.; Mathers, J.C. Digestion by pigs of nonstarch polysaccharides in wheat and raw peas (Pisum sativum) fed in mixed diets. Br. J. Nutr. 1991, 65, 259-270. [CrossRef]

66. Jha, R.; Bindelle, J.; Van Kessel, A.; Leterme, P. In vitro fibre fermentation of feed ingredients with varying fermentable carbohydrate and protein levels and protein synthesis by colonic bacteria isolated from pigs. Anim. Feed Sci. Technol. 2011, 165, 191-200. [CrossRef]

67. Jha, R.; Zijlstra, R.T. Physico-chemical properties of purified fiber affect their in vitro fermentation characteristics and are linked to in vivo characteristics in pigs. Can. J. Anim. Sci. 2018, 98, 394-398. [CrossRef]

68. Quiniou, N.; Noblet, J. Influence of high ambient temperatures on performance of multiparous lactating sows. J. Anim. Sci. 1999, 77, 2124-2134. [CrossRef]

69. Yang, H.; Xiang, Y.; Robinson, K.; Wang, J.J.; Zhang, G.L.; Zhao, J.C.; Xiao, Y.P. Gut microbiota is a major contributor to adiposity in pigs. Front. Microbiol. 2018, 9, 3045. [CrossRef]

70. Bouhnik, Y.; Raskine, L.; Simoneau, G.; Vicaut, E.; Neut, C.; Flourie, B.; Brouns, F.; Bornet, F.R. The capacity of nondigestible carbohydrates to stimulate fecal bifidobacteria in healthy humans: A double-blind, randomized, placebo-controlled, parallel-group, dose-response relation study. Am. J. Clin. Nutr. 2004, 80, 1658-1664. [CrossRef]

71. Dierick, N.A.; Vervaeke, I.J.; Demeyer, D.I.; Decuypere, J.A. Approach to the energetic importance of fibre digestion in pigs.I. Importance of fermentation in the overall energy supply. Anim. Feed Sci. Technol. 1989, 23, 141-167. [CrossRef] 
72. Varel, V.H.; Yen, J.T. Microbial perspective on fiber utilization by swine. J. Anim. Sci. 1997, 75, $2715-2722$. [CrossRef] [PubMed]

73. Knudsen, K.E.B.; Serena, A.; Canibe, N.; Juntunen, K.S. New insight into butyrate metabolism. Proc. Nutr. Soc. 2003, 62, 81-86. [CrossRef] [PubMed]

74. Ventanas, S.; Ventanas, J.; Ruiz, J.; Estevez, M. Iberian pigs for the development of high-quality cured products. Recent Res. Dev. Agric. Food Chem. 2005, 6, 27-53.

Publisher's Note: MDPI stays neutral with regard to jurisdictional claims in published maps and institutional affiliations.

(C) 2020 by the authors. Licensee MDPI, Basel, Switzerland. This article is an open access article distributed under the terms and conditions of the Creative Commons Attribution (CC BY) license (http://creativecommons.org/licenses/by/4.0/). 